\title{
Failure of Intravenous Morphine to Serve as an Effective Instrumental Reinforcer in Dopamine D2 Receptor Knock-Out Mice
}

\author{
Greg I. Elmer, ${ }^{1}$ Jeanne O. Pieper, ${ }^{2}$ Marcelo Rubinstein, ${ }^{3}$ Malcolm J. Low, ${ }^{4}$ David K. Grandy, ${ }^{5}$ and \\ Roy A. Wise ${ }^{2}$ \\ ${ }^{1}$ Neuroscience Program, Maryland Psychiatric Research Center, Department of Psychiatry, University of Maryland School \\ of Medicine, Baltimore, Maryland 21228, ${ }^{2}$ Behavioral Neuroscience Section, Intramural Research Program, National \\ Institute on Drug Abuse, National Institutes of Health, Baltimore, Maryland 21224, 3/ngebi, Conicet and Departamento de \\ Ciencias Biologicas, Facultad de Ciencias Exactas y Naturales, Universidad de Buenos Aires, Buenos Aires 1428, \\ Argentina, ${ }^{4}$ Vollum Institute and ${ }^{5}$ Department of Physiology and Pharmacology, Oregon Health and Sciences University, \\ Portland, Oregon 97201
}

\begin{abstract}
The rewarding effects of opiates are thought to be mediated through dopaminergic mechanisms in the ventral tegmental area, dopamine-independent mechanisms in the nucleus accumbens, or both. The purpose of the present study was to explore the contribution of dopamine to opiate-reinforced behavior using D2 receptor knock-out mice. Wild-type, heterozygous, and D2 knock-out mice were first trained to lever press for water reinforcement and then implanted with intravenous catheters. The ability of intravenously delivered morphine to maintain lever pressing in these mice was studied under two schedules of reinforcement: a fixed ratio 4 (FR4) schedule (saline, $0.1,0.3$, or $1.0 \mathrm{mg} / \mathrm{kg}$, per injection) and a progressive ratio $(\mathrm{PR})$ schedule (1.0 $\mathrm{mg} / \mathrm{kg}$, per injection). In the wild-type and heterozygous mice, FR4 behavior maintained by morphine
\end{abstract}

injections was significantly greater than behavior maintained by vehicle injections. Response rate was inversely related to injection dose and increased significantly in the wild-type and heterozygous mice when the animals were placed on the PR schedule. In contrast, the knock-out mice did not respond more for morphine than for saline and did not respond more when increased ratios were required by the PR schedule. Thus, morphine served as a positive reinforcer in the wild-type and heterozygous mice but failed to do so in the knock-out mice. Under this range of doses and response requirements, the rewarding effects of morphine appear to depend critically on an intact D2 receptor system.

Key words: self-administration; morphine; dopamine; D2 receptor; mice; knock-out
The mesolimbic dopamine system has been implicated in the rewarding effects of both the opiates and the psychomotor stimulants (Wise, 1998). Direct localized administration of opioids to the ventral tegmental area (VTA) and the nucleus accumbens (NAc) have reinforcing effects (Bozarth and Wise, 1981; Olds, 1982; Goeders et al., 1984; Devine and Wise, 1994). Morphine self-administration into the VTA is thought to be mediated by a dopamine-dependent mechanism, whereas morphine selfadministration into the NAc is thought to be mediated by a dopamine-independent mechanism. Local injections of opiates in the VTA are thought to act by inhibiting GABAergic neurons that normally suppress the activity of their dopaminergic neighbors (Johnson and North, 1992). Disinhibition of the dopamine projection neurons increases dopamine levels in the NAc which then decreases medium spiny output neuron activity. Local injections of opiates in NAc are thought to act independently of local dopaminergic terminals by directly decreasing the activity of GABAergic medium spiny output neurons (Hakan and Henriksen, 1989; Jiang and North, 1992; Wang et al., 1997). The relative

\footnotetext{
Received Dec. 3, 2001; revised March 5, 2002; accepted March 18, 2002.

This work was supported in part by National Institute on Drug Abuse (NIDA) Grant DA11888 and the Intramural Research Center, NIDA, National Institutes of Health. We thank Jamey Levy for expert technical assistance.

Correspondence should be addressed to Dr. Greg Elmer, Neuroscience Program, Maryland Psychiatric Research Center, Department of Psychiatry, University of Maryland School of Medicine, P.O. Box 21247, Maple and Locust Streets, Baltimore, MD 21228. E-mail: gelmer@mprc.umaryland.edu.

Copyright (C) 2002 Society for Neuroscience $0270-6474 / 02 / 220001-06 \$ 15.00 / 0$
}

importance of these two sites (dopamine-dependent VTA and dopamine-independent NAc) in the positive reinforcing effects of intravenous opiates is not clearly established.

Genetically engineered animals offer one of the more recently available techniques to be applied to neuropharmacological research. Although a substantive role for the $\mu$-opiate receptor in intravenous opiate self-administration has been demonstrated using knock-out (Becker et al., 2000; Sora et al., 2001), transgenic (Elmer et al., 1996), and $\mu$ receptor-deficient mice (Elmer et al., 1995), the role of dopamine has not been examined using dopamine receptor-deficient mice in the self-administration model. In the three studies that have used dopamine-related knock-out models, all have used the conditioned place preference (CPP) method to assess reward. Morphine-induced CPP in dopamine transporter knock-out mice is stronger than that in wild-type

This article is published in The Journal of Neuroscience, Rapid Communications Section, which publishes brief, peerreviewed papers online, not in print. Rapid Communications are posted online approximately one month earlier than they would appear if printed. They are listed in the Table of Contents of the next open issue of JNeurosci. Cite this article as: JNeurosci, 2002, 22:RC224 (1-6). The publication date is the date of posting online at www.jneurosci.org.

http://www.jneurosci.org/cgi/content/full/6412 
mice (Spielewoy et al., 2000). Two studies have used dopamine D2 receptor knock-out mice. One group found that previously drug-naive D2 receptor knock-out mice failed to show CPP after conditioning (Maldonado et al., 1997), whereas the other group found that previously drug-naive D2 receptor knock-out mice did show CPP (Dockstader et al., 2001).

The discrepancy between the two D2 knock-out studies and the unknown relationship between CPP and instrumental drug selfadministration leaves open the question of the relative importance of dopamine-dependent and dopamine-independent mechanisms in the positive reinforcing effects of opiates. The purpose of the present study was to explore the consequences of D2 dopamine receptor elimination on intravenous morphine selfadministration. The control of lever pressing behavior by intravenous morphine was assessed in D2 knock-out, wild-type, and heterozygous mice under two conditions: across three morphine doses in a fixed-ratio (FR) paradigm and at the highest of these doses in a progressive ratio $(\mathrm{PR})$ paradigm.

\section{MATERIALS AND METHODS}

\section{Animals}

Adult (60-120 d old) male dopamine D2 receptor knock-out $(n=13)$, heterozygous $(n=16)$, and wild-type $(n=20)$ mice weighing $\sim 21-30 \mathrm{gm}$ at the start of the experiment were used. The homologous recombination techniques and genealogy are described in detail in previous reports (Kelly et al., 1997, 1998). Briefly, a vector in which the $5^{\prime}$ half of exon 8 was eliminated (sequences encoding the sixth transmembrane domain through the $\mathrm{C}$ terminus) was electroporated into a D3 embryonic stem (ES) cell line (129/Sv derived). Positive clonal ES cells were injected into C57BL/6J blastocysts. Male chimerics were bred to C57BL/6J females to produce a heterozygous $\mathrm{F} 1$ population. These mice were then interbred to produce an F2 offspring with a slightly atypical Mendelian distribution of 1:5. Subsequently, D2 heterozygous mice were backcrossed to wildtype $\mathrm{C} 57 \mathrm{BL} / 6 \mathrm{~J}$ mice for a number of generations. The mice used in the current study were from the 10th generation.

All animals were experimentally naive, housed in groups of two to five in a temperature-controlled room $\left(21^{\circ} \mathrm{C}\right)$ with a $12 \mathrm{hr}$ light/dark cycle, and given ad libitum access to Purina Laboratory Chow and tap water before the start of the experimental procedure. The animals used in this study were maintained in facilities fully accredited by the American Association for the Accreditation of Laboratory Animal Care. The studies were conducted in accordance with the Guide for Care and Use of Laboratory Animals provided by the National Institutes of Health.

\section{Operant morphine-reinforced behavior}

Procedure overview. The following procedures were used to assess operant intravenous morphine self-administration behavior. First, all mice were trained on a modified progressive ratio schedule for water reinforcement. This procedure was used to confirm the ability of the knockout mice to learn and perform a lever press operant for a non-drug reinforcer. The modified progressive ratio was used to assess the range of lever pressing rates that could be expected from the various genotypes. Second, some of the water-trained mice were surgically implanted with intravenous catheters and then allowed to respond on an FR4 schedule of reinforcement for $1.0,0.3,0.1$, and then $0 \mathrm{mg} / \mathrm{kg}$ morphine. Data from these tests were used to determine whether morphine would maintain responding in a dose-dependent manner. The remaining water-trained mice were surgically implanted with intravenous catheters and then placed on a progressive ratio schedule of morphine reinforcement. Mice were randomly assigned to each schedule. Data from these experiments were used to make an initial determination of potential differences in the efficacy of our test dose of morphine as a reinforcer in the different genotypes.

Apparatus. Ten mouse operant chambers were used. Each chamber was equipped with one lever, a liquid solenoid, and a 22 ga liquid swivel. The lever was a balanced rocker arm that broke an infrared photo beam when $0.5 \mathrm{gm}$ of force was applied. Two stimulus lights were used: one was positioned to illuminate the translucent lever, and the other was positioned above the solenoid delivery spout. The lever light was illuminated during periods of drug availability; the second light was illuminated during drug delivery. During water training, lever pressing resulted in delivery of a drop $(\sim 5 \mu \mathrm{l})$ of water after completion of each fixed-ratio component. A Harvard $22 \mu \mathrm{l}$ syringe pump was used to deliver vehicle or drug. The syringe pump and stimulus lights were controlled by an integrated Coulborn (Allentown, PA) environmental control system and MedAssociates interface (St. Albans, VT). System control and data acquisition and storage were accomplished using MedAssociates software.

Water training. Naive subjects were water deprived for $24 \mathrm{hr}$ and then placed in the operant chamber. Initially, a single lever press turned on stimulus lights above a spout (FR1); a solenoid delivery system delivered a small amount of liquid in response to each lever press. After completion of each 50 reinforcements, there was an increase in the fixed ratio requirement $(\mathrm{FRX}+1)$. The experimental sessions were run $24 \mathrm{hr} / \mathrm{d}$ for $4 \mathrm{~d}$ with ad libitum access to food.

Surgery. After completion of the water training, subjects were surgically prepared with a catheter implanted in the jugular vein. Surgical procedures were performed under ketamine $(80 \mathrm{mg} / \mathrm{kg}$, i.p. $)$ - and xylazine $(16 \mathrm{mg} / \mathrm{kg}$, i.p.)-induced anesthesia. SILASTIC tubing (0.012 inch inner diameter) was implanted in the right jugular vein approximately to the level of the atrium. The catheter was passed subcutaneously and exited in the midscapular region. The catheter was connected to a tether/swivel system that was mounted to the skull of the mouse with dental cement. Subjects recovered full movement and eating and drinking habits 3-5 d after surgery. Catheter patency was checked at the end of the experimental protocols via acute dosing with pentobarbital. Only those animals with patent catheters were included in the analysis.

Morphine self-administration behavior: fixed ratio 4 dose-effect curve. After recovery from surgery (3-5 d), subjects $[n=12,10$, and 7 for the D2 wild-type (D2wt), D2 heterozygous (D2het), and D2 knock-out (D2ko) mice, respectively] were placed in the operant chamber and given access to $1.0,0.3,0.1$, and $0 \mathrm{mg} / \mathrm{kg}$ morphine per injection for $5,3,3$, and $8 \mathrm{~d}$, respectively. All subjects were run on an FR4 schedule of reinforcement. Completion of each FR resulted in the illumination of the overhead house light and stimulus lights above the spout. Injections of 5-8 $\mu \mathrm{l}$ (based on body weight) were given over a period of $15 \mathrm{sec}$. A $30 \mathrm{sec}$ time-out period, during which house and stimulus lights were out, followed the completion of each injection. All subjects had access to morphine $23 \mathrm{hr} / \mathrm{d}$ and ad libitum access to food and water $24 \mathrm{hr} / \mathrm{d}$. A 12 $\mathrm{hr}$ light/dark cycle was maintained (on 7 A.M., off 7 P.M.). A stimulus light illuminating the lever signaled morphine availability.

Morphine self-administration behavior: progressive ratio performance. In the second group of mice ( $n=8,6$ and 6 for the D2wt, D2het, and D2ko mice, respectively), subjects were placed in the operant chamber after surgery (3-5 d) and given access to $1.0 \mathrm{mg} / \mathrm{kg}$ morphine per injection for $7 \mathrm{~d}$ on an FR4 schedule of reinforcement. These subjects were then placed on a progressive ratio schedule. Completion of each ratio resulted in an increase in the ratio requirement to obtain the next reinforcement. The sequential ratio requirements were adapted from Roberts and Bennet $(1993)$ and were as follows: PR $(1,3,5,7,9,12,15,18,23,28,33,41$, $49,57,70,83,96,117,138,156,200,225,275,300,325,350,375,425,475$, $525,600)$. The experimental sessions were run 12 hr/d (8 P.M.- 8 A.M.) with ad libitum access to food and water. A $12 \mathrm{hr}$ light/dark cycle was maintained (on 7 A.M., off 7 P.M.). Animals remained in the operant chamber for the duration of the experiment. A stimulus light illuminating the lever signaled morphine availability.

Data analysis. Genetic differences in fixed-ratio performance were analyzed using a two way repeated-measures ANOVA using drug intake and the number of reinforcements obtained at each dose as dependent variables. Genetic differences in progressive ratio performance were analyzed using a two way repeated-measures ANOVA with the number of reinforcements as the dependent variable. Post hoc analysis for each schedule of reinforcement was conducted using contrast analysis (SuperAnova).

\section{RESULTS}

\section{Water training}

All genotypes were successfully trained to stable rates of lever pressing for water reinforcement (Fig. $1 A$ ), reaching stable water intake by the second day of responding and maintaining that intake despite increasing response requirements (Fig. 1B). Although each genotype reached stable response and intake rates, the D2 knock-out mice emitted fewer responses and consumed 

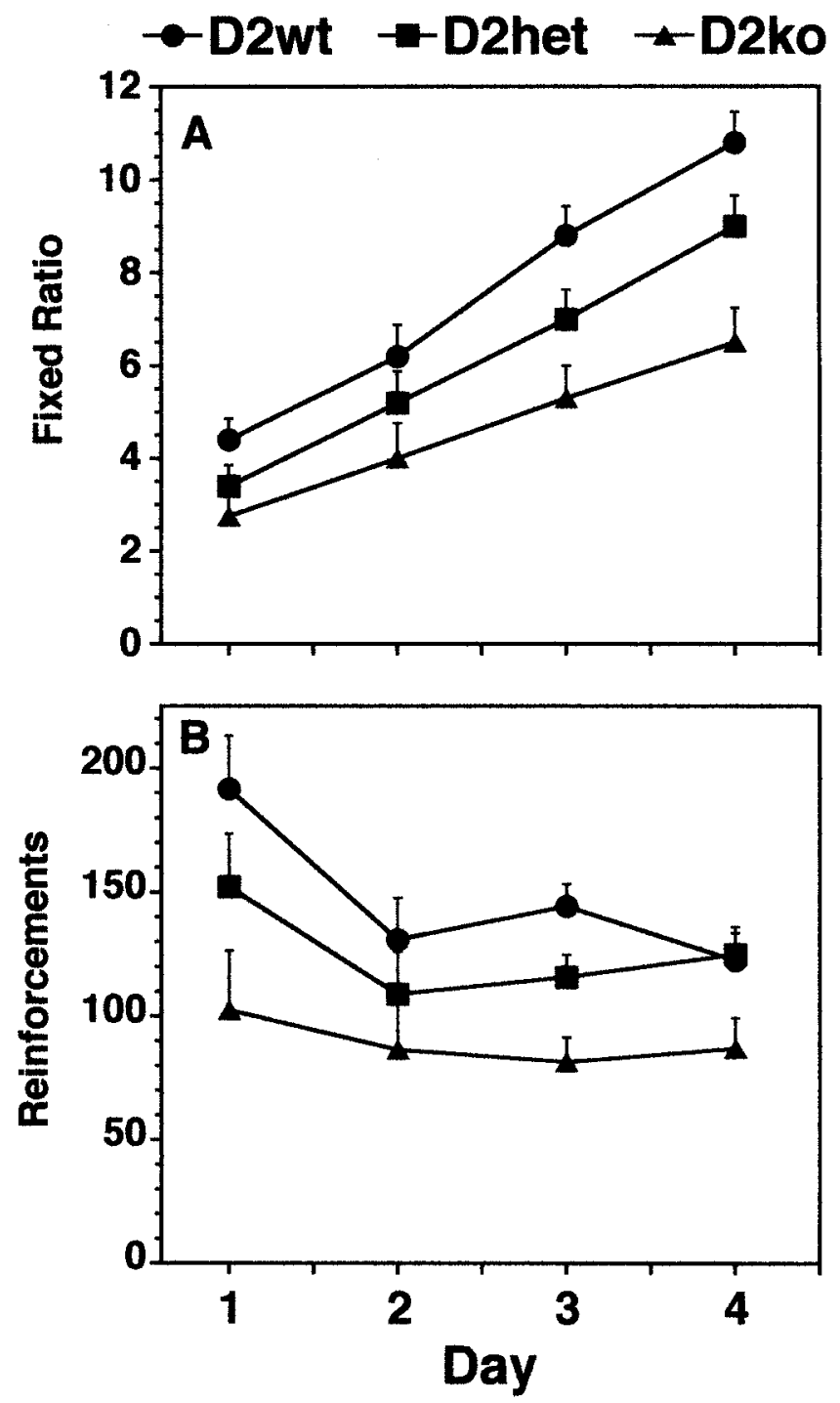

Figure 1. $A$ and $B$ represent the highest fixed ratio completed each day and the actual number of reinforcements obtained during the watertraining period, respectively. At the start of the water-training protocol, a single lever press resulted in liquid delivery; thereafter, completion of each 50 reinforcements resulted in an increase of the fixed ratio requirement $($ FRX +1$)$. The FR requirement was set to the previous day's last FR on days 2, 3, and 4. Each point represents the condition mean $( \pm$ SEM) of results from $12 \mathrm{D} 2 \mathrm{wt}, 10 \mathrm{D} 2 \mathrm{het}$, and 7 D2ko mice.

less water during the water-training period. There was a significant overall main effect of genotype for the fixed ratio obtained $\left(F_{\text {(Genotype)(2,27) }}=8.98 ; p<0.001\right)$ and number of reinforcements $\left(F_{\text {(Genotype)(2,27) }}=5.29 ; p<0.01\right)$. Additionally, a genotype by day interaction was found for reinforcements $\left(F_{(\text {Genotype } \times \text { Day })(6,78)}=2.66 ; p<0.02\right)$. Overall, D2ko mice consumed significantly less water when required to lever press to obtain water. When mice were given ad libitum access to water in their home cages, water consumption did not differ significantly across the three genotypes $(6.0 \pm 0.4,5.0 \pm 0.5$, and $6.2 \pm 0.4 \mathrm{ml}$ for the D2wt, D2het, and D2ko mice, respectively). The D2ko animals were clearly capable of lever pressing at rates of at least 566 responses per day. This would prove to be $\sim 15 \times$ the rate of responding sustained under morphine reinforcement.
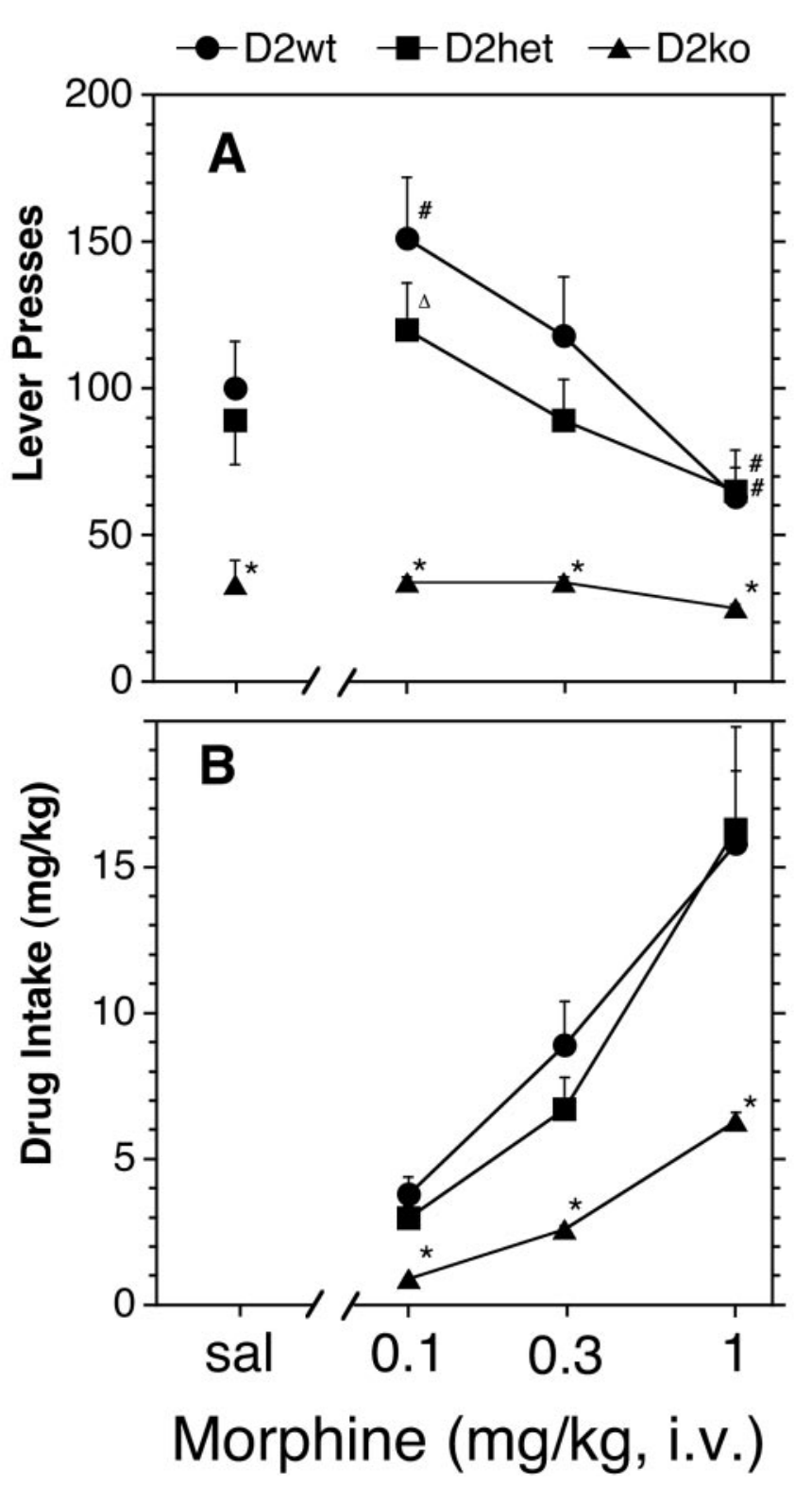

Figure 2. Lever pressing behavior $(A)$ and drug intake $(B)$ as a function of increasing morphine dose per injection. Each point represents the condition mean ( \pm SEM) of results from $12 \mathrm{D} 2 \mathrm{wt}, 10$ D2het, and 7 D2ko mice over the last three sessions of each condition. \# represents a significant difference from the saline control level of each genotype; $\triangle p<$ 0.06 from saline control; $*$ indicates a significant difference from wild type.

\section{Morphine self-administration behavior: fixed ratio 4 dose-effect curve}

The response rates of the D2wt and D2het mice were higher for low doses of drug than for saline (Fig. $2 A$ ). Although response rates for the D2wt and D2het mice decreased with increasing doses of morphine per injection, the response rates of the D2ko mice were the same for morphine as for saline and did not vary as a function of morphine dose. In the D2wt mice, injections of morphine maintained significantly greater and lesser amounts of behavior than saline at the $0.1(p<0.0367)$ and $1.0 \mathrm{mg} / \mathrm{kg}$ dose $(p<0.0052)$, respectively. In the D2het mice, the overall main effect of dose was significant; however, behavior maintained by the $0.1 \mathrm{mg} / \mathrm{kg}$ dose was only marginally greater than behavior 
maintained by saline $(p<0.0936)$, whereas behavior maintained by the $1.0 \mathrm{mg} / \mathrm{kg}$ dose was significantly less $(p<0.0328)$. In the D2ko mice, there was no significant difference between lever pressing for saline and lever pressing for morphine; furthermore, there were no significant differences in the responding across the three morphine dose conditions ( $p<0.63$; NS). Morphine intake in the D2ko mice was predictable from the rate of responding under saline reinforcement; the animals made the same 35 or so responses per day regardless of morphine dose and passively received the amount of drug that accompanied that number of responses at each dose (Fig. $2 B$ ). The overall main effects of dose, genotype, and genotype $\times$ dose interaction were significant for the number of lever presses maintained by morphine injections: $F_{(\text {Dose })}=10.93, \mathrm{df}=3,78, p<0.0001 ; F_{\text {(Genotype })}=$ 3.77 , df $=2,78, p<0.02 ; F_{\text {(Genotype } \times \text { Dose })}=2.37$, df $=6,78$, $p<0.036$. There was a dose-related change in the amount of behavior maintained at each dose in the D2wt $\left(F_{\text {(Dose) }}=9.30\right.$, $\mathrm{df}=3,33, p<0.0001)$ and D2het mice $\left(F_{(\text {Dose })}=5.37, \mathrm{df}=3,33\right.$, $p<0.005)$. There was a significant main effect of genotype and dose and a significant genotype $\times$ dose interaction on drug intake: $F_{\text {(Genotype) }}=2.7, \mathrm{df}=2,23, p<0.02 ; F_{(\text {Dose })}=8.7, \mathrm{df}=$ $2,23, p<0.002 ; F_{(\text {Genotype } \times \text { Dose) }}=7.8, \mathrm{df}=4,23, p<0.03$.

\section{Morphine self-administration behavior: progressive ratio performance}

Under progressive ratio conditions, the D2wt and D2het animals increased their response rates as response demands increased, whereas the D2ko animals responded no more on the progressive ratio schedule than they had responded for either saline or morphine on the FR schedule (Fig. 3). Lever pressing increased significantly in the D2wt and D2het mice but not in the D2ko mice $(p<0.02, p<0.02, p=0.24$, respectively). The overall main effects of schedule and genotype as well as the genotype by schedule interaction for the number of injections received were significant: $\left(F_{(\text {Schedule })(1,17)}=16.9, p<0.0008 ; F_{(\text {Genotype })(2,17)}=\right.$ $5.77, p<0.02 ; F_{\text {(Genotype } \times \text { Schedule)(1,17) }}=3.3, \mathrm{df}=1,17, p<0.05$. Thus, in the D2ko animals, morphine again failed to sustain levels of responding greater than those sustained by saline. Under saline or morphine conditions (any dose or schedule), the D2ko animals responded at $<1 / 10$ the rates that had been sustained under water reinforcement.

\section{DISCUSSION}

Intravenous morphine delivery did not serve as a positive reinforcer in dopamine D2 receptor knock-out mice under conditions that were effective in the wild-type and heterozygous mice. D2ko mice responded at the same low levels for intravenous saline and intravenous morphine and did not alter their rate of responding when morphine doses were altered. D2wt and D2het mice responded at increased rates for the low dose of morphine and at decreased rates for the high dose of morphine. Thus the behavior of the D2wt and D2het animals was under the pharmacological control of morphine, whereas the behavior of the D2ko animals was not. That the D2ko animals were capable of responding more than they did for morphine seems clear from their level of responding for water during the water-training period. That they were not incapacitated by the morphine itself was clear from the fact that the same low rate of responding seen with intravenous saline was also seen with intravenous morphine. Thus morphine served effectively as a reinforcer in D2wt and D2het mice, but served no more effectively than intravenous saline reinforcement, and much less effectively than oral water reinforcement, in D2ko

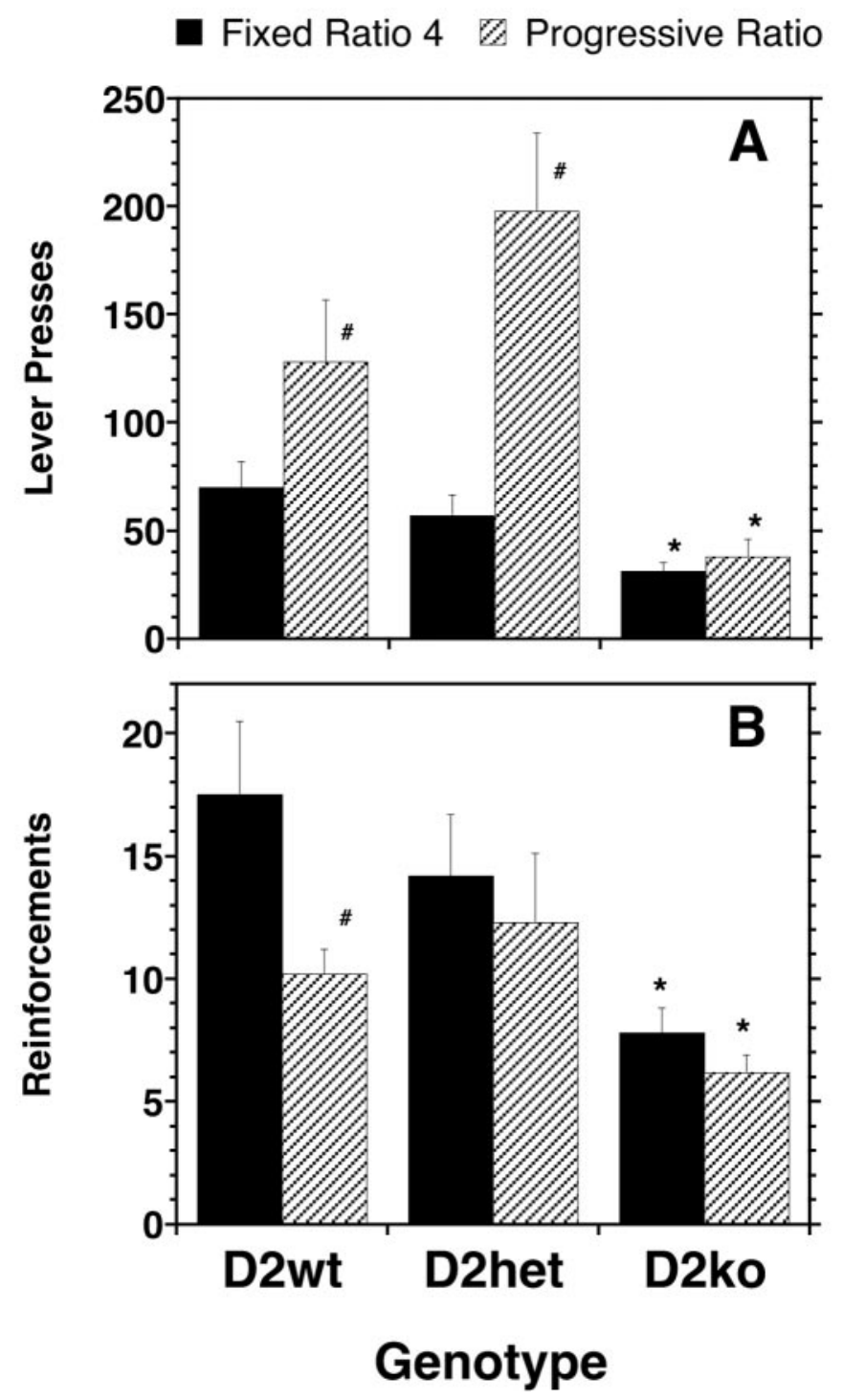

Figure 3. Number of lever presses $(A)$ and reinforcements $(B)$ obtained under a fixed-ratio 4 and progressive-ratio schedule of reinforcement. Each point represents the condition mean $( \pm$ SEM) of results from eight $\mathrm{D} 2 \mathrm{wt}$, six D2het, and six D2ko mice over the last three sessions of each condition. Asterisk indicates a significant difference from D2wt and D2het mice; \# represents a significant difference from FR4 values.

mice. Across the normally effective dose range, intravenous morphine seems unable to serve as a normal reinforcer in D2ko mice. Under the conditions described in this report, the rewarding effects of morphine appear to depend on an intact or a partially intact D2 receptor system.

Previous dialysis and voltammetry studies have suggested involvement of dopamine in morphine-reinforced behavior (Di Chiara and Imperato, 1988; Devine et al., 1993; Wise et al., 1995; Kiyatkin and Rebec, 2001). These studies, however, are correlative in nature and do not provide evidence that would identify which component of the dopamine system may be involved. Studies involving dopamine antagonists have not consistently confirmed a role for dopamine in opiate reinforcement (Ettenberg et al., 1982; van Ree and Ramsey, 1987; Gerber and Wise, 1989; Gerrits et al., 1994). In these studies, which used competitive dopamine antagonists with varying selectivity for dopamine receptor subtypes, the completeness of dopamine blockade could 
not be assessed. Genetically engineered animals provide a model with partial and complete receptor elimination. Using this model, the evidence provided in the current study suggests that a $50 \%$ complement of D2 receptors is sufficient to maintain morphine self-administration, whereas complete elimination of D2 receptors is not.

Conflicting conclusions have been reached using D2 receptor knock-out mice in CPP models (Maldonado et al., 1997; Dockstader et al., 2001). Maldonado et al. (1997) found that drug-naive D2ko mice did not show morphine-conditioned place preferences, whereas Dockstader et al. (2001) found that previously drug-naive D2ko mice did. Neither study investigated CPP in heterozygote mice. The two studies used similar dose ranges, but different methods were used to eliminate the $\mathrm{D} 2$ receptor genes. In addition, a mixed genetic background $($ C57BL $\times 129)$ was used in the Maldonado et al., (1997) report, whereas a fifth generation congenic C57BL/6J background was used in the Dockstader et al. (2001) report. Differences in background genotype were offered to explain the discrepancies. However, the animals used in the present study were the 10th generation of the same knock-out line that was used by Dockstader et al. (2001). On the basis of further studies, Dockstader et al. (2001) suggested that CPP failed to develop in the D2ko mice only if the animals were first made physically dependent on morphine (Bechara et al., 1992). In the present study the animals were not opiate-dependent, yet intravenous morphine, at any of three normally effective doses, failed to serve as an effective reinforcer.

Genetically manipulated animal models provide a means to eliminate a receptor system with a high degree of specificity. However, embryonic gene manipulation is unlikely to affect a single behavior or a single receptor system. As an example of pleiotropic effects on behavior, D2 knock-out mice emitted fewer responses during the water-training period in addition to the instrumental morphine reinforced period. Water consumption in the home cage did not differ significantly across the three groups of mice. The selective effect on instrumental responding may be explained by the fact that dopamine antagonists disrupt instrumental behaviors at lower doses than are required to disrupt free consumption of the reward in question (Gramling and Fowler, 1985). The decreased responding in the knock-outs is also consistent with the notion that dopamine plays a fundamental role in the rewarding impact of food, water, and other positive reinforcers (Wise and Rompre, 1989). The general involvement of D2 receptors in motivated behavior will be important to investigate further (Risinger et al., 2000). As an example of pleiotropic effects on neurotransmitters, D2 knock-out mice have reduced glial cell line-derived neurotrophic factor (Bozzi and Borrelli, 1999), dopamine transporter function (Dickinson et al., 1999), striatal medium spiny neurons (Cepeda et al., 2001), adenosine $\mathrm{A}(2 \mathrm{~A})$ receptor function (Zahniser et al., 2000), and substance $\mathrm{P}$ mRNA levels (Murer et al., 2000). One of these secondary alterations may be a necessary cofactor to $\mathrm{D} 2$ receptor function in determining opiate reward (i.e., substance P) (Murtra et al., 2000). Although several caveats exist with embryonic gene manipulation, it is important to note that D2 knock-out mice have a normal complement of $\mu$-opiate receptors (Maldonado et al., 1997) and show other opiate-mediated behaviors (Drago et al., 1999). In addition, the D2ko mice are capable of significant instrumental responding (i.e., 566 lever presses during the last day of water-reinforced behavior), but such responding is not sustained by morphine reward. Overall, the evidence provided in this report clearly supports the conclusion that an intact D2 receptor system is an important component of opiate reward mechanisms.

\section{REFERENCES}

Bechara A, Harrington F, Nader K, van der Kooy D (1992) Neurobiology of motivation: double dissociation of two motivational mechanisms mediating opiate reward in drug-naive versus drug-dependent animals. Behav Neurosci 106:798-807.

Becker A, Grecksch G, Brodemann R, Kraus J, Peters B, Schroeder H, Thiemann W, Loh HH, Hollt V (2000) Morphine self-administration in mu-opioid receptor-deficient mice. Naunyn Schmiedebergs Arch Pharmacol 361:584-589.

Bozarth MA, Wise RA (1981) Intracranial self-administration of morphine into the ventral tegmental area in rats. Life Sci 28:551-555.

Bozzi Y, Borrelli E (1999) Absence of the dopamine D2 receptor leads to a decreased expression of GDNF and NT-4 mRNAs in restricted brain areas. Eur J Neurosci 11:1275-1284.

Cepeda C, Hurst RS, Altemus KL, Flores-Hernandez J, Calvert CR, Jokel ES, Grandy DK, Low MJ, Rubinstein M, Ariano MA, Levine MS (2001) Facilitated glutamatergic transmission in the striatum of D2 dopamine receptor-deficient mice. J Neurophysiol 85:659-670.

Devine DP, Wise RA (1994) Self-administration of morphine, DAMGO, and DPDPE into the ventral tegmental area of rats. J Neurosci 14:1978-1984.

Devine DP, Leone P, Pocock D, Wise RA (1993) Differential involvement of ventral tegmental mu, delta and kappa opioid receptors in modulation of basal mesolimbic dopamine release: in vivo microdialysis studies. J Pharmacol Exp Ther 266:1236-1246.

Di Chiara G, Imperato A (1988) Drugs abused by humans preferentially increase synaptic dopamine concentrations in mesolimbic system of freely moving rats. Proc Natl Acad Sci USA 85:5274-5278.

Dickinson SD, Sabeti J, Larson GA, Giardina K, Rubinstein M, Kelly MA, Grandy DK, Low MJ, Gerhardt GA, Zahniser NR (1999) Dopamine D2 receptor-deficient mice exhibit decreased dopamine transporter function but no changes in dopamine release in dorsal striatum. J Neurochem 72:148-156.

Dockstader CL, Rubinstein M, Grandy DK, Low MJ, van der Kooy D (2001) The D2 receptor is critical in mediating opiate motivation only in opiate-dependent and withdrawn mice. Eur J Neurosci 13:995-1001.

Drago F, Contarino A, Busa L (1999) The expression of neuropeptideinduced excessive grooming behavior in dopamine D1 and D2 receptor-deficient mice. Eur J Pharmacol 365:125-131.

Elmer GI, Pieper JO, Goldberg SR, George FR (1995) Opioid operant self-administration, analgesia, stimulation and respiratory depression in mu-deficient mice. Psychopharmacology 117:23-31.

Elmer GI, Evans JL, Goldberg SR, Epstein CJ, Cadet JL (1996) Transgenic superoxide dismutase mice: increased opioid mesolimbic $\mu$-opioid receptors results in greater opioid-induced stimulation and opioid-reinforced behavior. Behav Pharmacol 7:628-639.

Ettenberg A, Pettit HO, Bloom FE, Koob GF (1982) Heroin and cocaine intravenous self-administration in rats: mediation by separate neural systems. Psychopharmacology 78:204-209.

Gerber GJ, Wise RA (1989) Pharmacological regulation of intravenous cocaine and heroin self-administration in rats: a variable dose paradigm. Pharmacol Biochem Behav 32:527-531.

Gerrits MA, Ramsey NF, Wolterink G, van Ree JM (1994) Lack of evidence for an involvement of nucleus accumbens dopamine D1 receptors in the initiation of heroin self-administration in the rat. Psychopharmacology 1994:486-494.

Goeders NE, Lane JD, Smith JE (1984) Self-administration of methionine enkephalin into the nucleus accumbens. Pharmacol Biochem Behav 20:451-455.

Gramling SE, Fowler SC (1985) Effects of neuroleptics on rate and duration of operant versus reflexive licking in rats. Pharmacol Biochem Behav 22:541-545.

Hakan RL, Henriksen SJ (1989) Opiate influences on nucleus accumbens electrophysiology: dopamine and non-dopamine mechanisms. J Neurosci 9:3538-3546.

Jiang ZG, North RA (1992) Pre- and postsynaptic inhibition by opioids in rat striatum. J Neurosci 12:356-361.

Johnson SW, North RA (1992) Opioids excite dopamine neurons by hyperpolarization of local interneurons. J Neurosci 12:483-488.

Kelly MA, Rubinstein M, Asa SL, Zhang G, Saez C, Bunzow JR, Allen RG, Hnasko R, Ben-Jonathan N, Grandy DK, Low MJ (1997) Pituitary lactotroph hyperplasia and chronic hyperprolactinemia in dopamine D2 receptor-deficient mice. Neuron 19:103-113.

Kelly MA, Rubinstein M, Phillips TJ, Lessov CN, Burkhart-Kasch S, Zhang G, Bunzow JR, Fang Y, Gerhardt GA, Grandy DK, Low MJ (1998) Locomotor activity in D2 dopamine receptor-deficient mice is determined by gene dosage, genetic background, and developmental adaptations. J Neurosci 18:3470-3479.

Kiyatkin EA, Rebec GV (2001) Impulse activity of ventral tegmental area neurons during heroin self-administration in rats. Neuroscience 102:565-580. 
Maldonado R, Saiardi A, Valverde O, Samad TA, Roques BP, Borrelli E (1997) Absence of opiate rewarding effects in mice lacking dopamine D2 receptors. Nature 388:586-589.

Murer MG, Dziewczapolski G, Salin P, Vila M, Tseng KY, Ruberg M, Rubinstein M, Kelly MA, Grandy DK, Low MJ, Hirsch E, RaismanVozari R, Gershanik O (2000) The indirect basal ganglia pathway in dopamine $\mathrm{D}(2)$ receptor-deficient mice. Neuroscience 99:643-650.

Murtra P, Sheasby AM, Hunt SP, De Felipe C (2000) Rewarding effects of opiates are absent in mice lacking the receptor for substance P. Nature 405:180-183.

Olds ME (1982) Reinforcing effects of morphine in the nucleus accumbens. Brain Res 237:429-440.

Risinger FO, Freeman PA, Rubinstein M, Low MJ, Grandy DK (2000) Lack of operant ethanol self-administration in dopamine D2 receptor knockout mice. Psychopharmacology 152:343-350.

Roberts DCS, Bennet SAL (1993) Heroin self-administration in rats under a progressive ratio schedule of reinforcement. Psychopharmacology 111:215-218.

Sora I, Elmer G, Funada M, Pieper J, Li X, Hall FS, Uhl GR (2001) Mu opiate receptor gene dose effects on different morphine actions. Evidence for differential in vivo mu receptor reserve. Neuropsychopharmacology 25:41-54.

Spielewoy C, Gonon F, Roubert C, Fauchey V, Jaber M, Caron MG, Roques BP, Hamon M, Betancur C, Maldonado R, Giros B (2000)
Increased rewarding properties of morphine in dopamine-transporter knockout mice. Eur J Neurosci 12:1827-1837.

van Ree JM, Ramsey NF (1987) The dopamine hypothesis of opiate reward challenged. Eur J Pharmacol 134:239-243.

Wang H, Moriwaki A, Wang JB, Uhl GR, Pickel VM (1997) Ultrastructural immunocytochemical localization of mu-opioid receptors in dendritic targets of dopaminergic terminals in the rat caudate-putamen nucleus. Neuroscience 81:757-771.

Wise RA (1989) The brain and reward. In: The neuropharmacological basis of reward (Liebman JM, Cooper SJ, eds), pp 377-424. Oxford: Oxford UP.

Wise RA (1998) Drug-activation of brain reward pathways. Drug Alcohol Depend 51:13-22.

Wise RA, Rompre PP (1989) Brain dopamine and reward. Annu Rev Psychol 40:191-225.

Wise RA, Leone P, Rivest R, Leeb K (1995) Elevations of nucleus accumbens dopamine and DOPAC levels during intravenous heroin self-administration. Synapse 21:140-148.

Zahniser NR, Simosky JK, Mayfield RD, Negri CA, Hanania T, Larson GA, Kelly MA, Grandy DK, Rubinstein M, Low MJ, Fredholm BB (2000) Functional uncoupling of adenosine $\mathrm{A}(2 \mathrm{~A})$ receptors and reduced response to caffeine in mice lacking dopamine D2 receptors. J Neurosci 20:5949-5957. 